\title{
Etnis Tionghoa dan Arab di Banda, Maluku \\ (Studi Tentang Integrasi Berdasarkan Kepentingan Ekonomi-Politik Melalui Pendekatan Ekologi Politik)
}

\section{Chinese and Arabic ethnics in Banda, Maluku \\ (Study of Integration Based on Economic-Political Consideration through Political Ecology Approach)}

\author{
Hartanto Rosojati ${ }^{\mathrm{a}, 1}$ \\ a, Fakultas Ilmu Sosial dan Ilmu Politik, Universitas Indonesia, Indonesia \\ ${ }^{1}$ hrosojati@gmail.com
}

\begin{tabular}{ll}
\hline Informasi artikel & ABSTRAK \\
\hline Kata kunci: & Tulisan ini mengargumentasikan tentang integrasi ekonomi-politik yang \\
Integrasi & dilakukan etnis Tionghoa dan etnis Arab di Kepulauan Banda, Maluku. \\
Tionghoa & Integrasi merupakan praktik adaptif dari individu/kelompok dengan cara \\
Arab & saling menghargai kebudayaan dan hubungan antarkelompok lain, serta \\
Ekonda & kebudayaan dari masing-masing kelompok tidak merasa diancam. \\
Politik Ekologi & Meskipun demikian, interaksi dalam waktu yang panjang tersebut selalu \\
& memiliki konsekuensi lain, yaitu kepentingan ekonomi ataupun politik. \\
& Pada dasarnya ekonomi dan politik adalah hasil dari manifestasi interaksi \\
& masyarakat yang selalu didasari dari basis material. Ekonomi dan politik \\
& tidak berdiri secara tunggal, melainkan menjadi kesatuan yang merujuk \\
& pada bentuk power yang digunakan untuk melihat bagaimana bentuk \\
& pengorganisasian dilakukan dalam sebuah masyarakat. Untuk \\
menjelaskan konteks ekonomi-politik, artikel ini menggunakan \\
pendekatan ekologi politik. Hasilnya menunjukkan bahwa ada \\
pengintegrasian melalui pembagian kekuasaan dalam ekonomi-politik \\
dengan membagi sumberdaya ekologis yang ada di Banda yang dilakukan \\
oleh etnis Tionghoa dan etnis Arab. Data dalam artikel ini diperoleh dari \\
hasil observasi lapangan, penelitian lapangan, serta studi pustaka tentang \\
Tionghoa, Arab, dan Banda.
\end{tabular}

Keywords:

Integration

Tionghoa

Arab

Banda

Political-economy

Ecology Politic

\section{ABSTRACT}

Chinese and Arabic ethnics in Banda, Maluku (Study of Integration Based on Economic-Political Consideration through Political Ecology Approach). This paper argues about the political-economic integration carried out by ethnic Chinese and Arab ethnic groups in the Banda Islands, Maluku. Integration is an adaptive practice of individuals / groups by way of mutual respect for culture and relationships between other groups, and the culture of each group doesn't feel threatened. However, this long-term interaction always has other consequences, that's economic or political interests. Basically economics and politics are the result of manifestations of community interaction which are always based on a material basis. Economics and politics do not stand alone, but rather become a unit that refers to the form of power used to see how the form of organizing is carried out in a society. To explain the political-economic context, this article uses a political ecology approach. The results show that there is integration through power sharing in the political economy by dividing the existing ecological resources in Banda by ethnic Chinese and Arab ethnic groups. The data in this article was obtained from the results of field observations, field research, and literature studies on Chinese, Arabic, and Banda. 


\section{Pendahuluan}

Proses menjadi Indonesia ditandai dari sejarah panjang terjadinya silang etnis. Hal ini tidak terhindarkan mengingat berbagai bangsa pernah menginjakkan kaki di tempat tumbuh suburnya rempah-rempah. Peradaban bangsabangsa di Indonesia memang diawali dengan adanya perdagangan. Dari pola inilah kemudian intensitas dalam berinteraksi antarbangsa-bangsa semakin intensif. Berbagai macam ciri khas dari masing-masing kebudayaan dalam rentang waktu yang panjang saling bersinggungan. Proses inilah yang kemudian memunculkan bentuk-bentuk dari akulturasi. Menurut Schwartz (et al., 2010), akulturasi dipahami sebagai sebuah proses multidimensi yang di dalamnya terdapat pertalian antara nilai, praktik, dan identifikasi budaya. Proses ini tidak dapat berlangsung singkat, melainkan butuh waktu yang panjang. Meski rentang waktu tidak dijelaskan secara lebih rinci namun karena terdapat pemahaman antarnilai jelas membutuhkan waktu yang tidak sebentar. Selain proses yang multidimensi, akulturasi juga selalu didasarkan untuk melihat jenis kekuasaan yang mempengaruhi proses akulturasi tersebut. Dimensi ini berusaha untuk melihat bagaimana tindakan dari kelompok penerima dan konteks global tentang prosesnya (Guarnaccia \& Stabile, 2016).

Salah satu konsekuensi dari persinggungan atau hasil akulturasi adalah proses integrasi dari satu kebudayaan atau lebih. Dalam prosesnya, individu berusaha terintegrasi dengan kebudayaan lain yang lebih besar. Kondisi ini dapat mungkin terjadi pada masyarakat majemuk, dengan catatan masyarakat yang lebih besar atau dominan menerima kelompok budaya baru tanpa memberi tekanan kepada kelompok yang lebih kecil. Selain itu pihak yang melakukan integrasi juga merasa bahwa budayanya tidak sedang diancam, atau kata lain budayanya dihormati oleh kelompok yang lebih besar (Nwadoria \& NcAdoo, 1996). Kondisi tersebut sesuai dengan apa yang terjadi di Banda, Maluku Tengah.

Ratusan tahun yang lalu, Banda terkenal dengan hasil rempah-rempah seperti pala dan fuli yang mendunia. Berbagai bangsa-bangsa datang untuk melakukan perdagangan, bahkan berusaha untuk menguasai Banda secara politik terhadap sumber daya ekologis yang ada. Bangsa Tionghoa dan Arab sudah berada di Banda jauh sebelum kedatangan bangsa Eropa seperti Portugis, Inggris, dan Belanda. Namun, riwayat kedua etnis tersebut yaitu Tionghoa dan Arab tidak terlalu banyak dibahas dalam beberapa studi yang ada. Mereka hanya sebagai masyarakat luar yang dikenal hanya melakukan perdagangan. Selebihnya riwayat atau sejarah Belanda dan pertempuran dengan penduduk Banda menjadi dominan dalam wacana-wacana terkait Banda. Selain itu yang paling dikenal adalah peristiwa pada tahun 1667, yaitu peristiwa terjadinya perjanjian Breda yang berisi tentang penukaran wilayah koloni dari Belanda dan Inggris. Belanda memberikan daerah kekuasaannya yaitu Manhattan ke Inggris, sedangkan Inggris memberikan wilayah kekuasaannya yaitu Pulau Rhun di Banda ke pihak Belanda. Peristiwa tersebut juga merupakan wujud dari politik ekologi kaitannya dengan penguasaan secara penuh serikat dagang Belanda yaitu VOC untuk memonopoli rempah-rempah di Banda. 
Peristiwa yang tidak kalah penting adalah jauh sebelum perjanjian Breda dilaksanakan, yaitu peristiwa genoshida pada tahun 1621. Pada tahun tersebut, Jenderal VOC JP Coen berhasil membunuh 44 orangkaya Banda. Istilah orangkaya merujuk pada tokoh atau pemimpin di beberapa wilayah di Banda. Mereka dianggap sebagai seseorang yang identitasnya identik dengan jabatan politik dan memiliki kekayaan secara ekonomi. Orangkaya dibunuh karena mereka sangat berpengaruh dalam mekanisme perdagangan pala di kawasan Banda, sehingga hal tersebut dianggap mengganggu jalannya monopoli dagang yang dilakukan oleh VOC. Orangkaya tersebut biasanya menjabat sebagai kepala desa (Villiers, 1981). Bahkan tidak hanya orangkaya yang dibunuh, melainkan masyarakat Banda secara keseluruhan juga banyak yang dibunuh. Namun sekali lagi peristiwa tersebut tidak menjelaskan di mana keberadaan etnis Tionghoa dan Arab sebagai etnis yang juga melakukan perdagangan di Banda. Ketika kejayaan kolonial berakhir, dan bangsabangsa Eropa tidak lagi mendiami Banda, etnis Tionghoa dan Arab masih dapat dijumpai hingga kini. Hal yang menarik adalah bagaimana integrasi Tionghoa dan Arab dilakukan di Banda. Integrasi merujuk pada hubungan yang saling menghargai antarkelompok baik Tionghoa dan Arab dengan etnis Banda. Kondisi ini juga terlihat dari kehidupan yang harmonis karena tidak ada tekanan kepada kelompok-kelompok etnis yang ada di Banda. Relasi integrasi ini coba dilihat melalui hubungan antara Tionghoa dan Arab dengan pendekatan politik ekologis. Pendekatan ini digunakan berdasarkan riwayat sejarah bahwasanya Banda dipolitisasi untuk dimanfaatkan sumberdaya ekologisnya, lalu ketika kejayaan Banda sebagai penghasil rempah runtuh seiring dengan berkahirnya masa kejayaan perkeniers, lantas bagaimana pengintegrasian etnis Tionghoa dan Arab di Banda dalam pengelolaan ekonomi-politik. Permasalahan tersebut dimaksudkan untuk dapat menjelaskan bagaimana relasi antaretnik yang terjadi di Banda, serta bagaimana penguasaan sumber daya secara ekologis dilakukan untuk melihat pola penguasaan ekonomi-politik Banda. Artikel ini juga memperlihatkan bagaimana pendekatan ekologi politik digunakan untuk melihat integrasi yang terjadi dari interaksi panjang etnis Tionghoa dengan etnis Arab yang ada di Banda.

\section{Metode}

Penelitian lapangan dilakukan di Kecamatan Banda, Kabupaten Maluku Tengah, Provinsi Maluku pada rentang waktu April hingga Mei 2018. Selain itu data dalam artikel ini juga diperoleh melalui hasil pengamatan panjang hingga Oktober 2019 melalui komunikasi intensif dengan para informan yang diperoleh saat penelitian lapangan. Penelitian ini dilakukan dengan studi yang bersifat etnografis pada etnis Tionghoa dan etnis Arab di Banda. Kedua etnis ini adalah etnis yang secara ekonomi-politik berpengaruh dalam kehidupan ekonomi-politik di Banda. Artikel ini melihat ada relasi yang dibangun melalui pemanfaatan sumber daya alam dan sumber daya lain yang memungkinkan untuk terjadinya penguasaan secara politik dan terjadinya bentuk integrasi. Secara lebih spesifik, penelitian ini dilakukan dengan cara wawancara mendalam dengan subjek penelitian yaitu etnis Tionghoa dan Etnis Arab. Untuk menjelaskan relasi antarkedua etnik tersebut juga dibutuhkan etnis Banda sebagai informan untuk dilakukan triangulasi data dalam melihat keberadaan etnis pendatang di sana. Beberapa informan kunci dalam penelitian ini adalah para pelaku bisnis 
yang kuat secara modal ekonomi dan politik baik dari etnis Tionghoa dan etnis Arab.

\section{Pembahasan}

Melalui perjalanan panjang silang etnis, bentuk-bentuk akulturasi sudah menjadi keniscayaan. Kondisi ini sudah semestinya terjadi ketika berbagai kebudayaan melakukan proses interaksi yang sangat lama. Seringkali istilah akulturasi disandingkan dengan istilah asimilasi. Padahal asimilasi menjadi salah satu hasil dari akulturasi, serta kedua istilah tersebut sangatlah berbeda. Asimilasi lebih mengacu pada hilangnya identitas asli dari individu atau kelompok dan mengarah pada penyerapan ke kebudayaan yang lebih dominan, sedangkan akulturasi tidak dalam ranah menghilangkan suatu identitas dari individu atau kelompok tertentu (Weinstock, 1969). Perbedaan antara akulturasi dan asimilasi pun juga dilihat Teske dan Nelson (1974) dalam artikelnya untuk American Ethnologist. Menurutnya, akulturasi merupakan proses yang sangat dinamis dan bukan peristiwa yang tunggal, melainkan seperangkat proses yang sangat panjang. Proses ini selalu diyakini sebagai proses yang dua arah. Melalui proses ini, Teske dan Nelson menitikberatkan pada peran dari kekuasaan dalam proses akulturasi. Adanya peran kuasa tersebut terjadi karena proses politik. Dalam pengaplikasiannya, penelitian tentang akulturasi harus melibatkan dimensi yang kontekstual seperti dinamika sosial, ekonomi, dan politik, karena proses akulturasi selalu terjadi dalam konteks tersebut bahkan dalam tataran ekologis. Konteks globalisasi saat ini juga menunjukkan bahwa persinggungan antarkelompok dalam konteks kehidupan sosial semakin banyak. Pertemuan inilah yang kemudian memunculkan berbagai macam respon dengan berbagai macam cara.

Proses akulturasi sesuai yang sudah dijelaskan sebelumnya merupakan bentuk interaksi dua kebudayaan atau lebih dengan beberapa macam konsekuensi bentukannya, yang antara lain adalah assimilation, integration, deculturation, dan rejection (Nwadoria \& NcAdoo, 1996). Asimilasi dapat diartikan sebagai pengadopsian terhadap kebudayaan lain, yang dalam hal ini sebagai budaya yang dianggap dominan. Pada konteks asimilasi ada penerimaan terhadap budaya lain yang konsekuensinya budaya yang melekat dalam individu atau kelompok dapat dikatakan hilang. Kecenderungan hilangnya identitas ini lebih besar terjadi pada individua tau kelompok yang lebih kecil atau mnoritas. Integrasi merujuk pada individu atau kelompok yang menghargai kebudayaan dan hubungan antarkelompok. Dalam prosesnya, individu mencoba untuk terintegrasi dengan kelompok lain yang lebih besar dengan mempertahankan karakteristik budaya sendiri. Kondisi ini dapat mungkin terjadi pada masyarakat majemuk, dengan catatan masyarakat yang lebih besar atau dominan menerima kelompok budaya baru tanpa memberi tekanan kepada kelompok yang lebih kecil. Selain itu pihak yang melakukan integrasi juga merasa bahwa budayanya tidak sedang diancam, atau kata lain budayanya dihormati oleh kelompok yang lebih besar. Dekulturasi berarti ketika pendatang atau kelompok yang lebih kecil mengalami kebingungan dan merasa terasing yang akibatnya menyerang budaya yang dominan. Kondisi ini sangat mungkin terjadi ketika kebudayaannya diremehkan oleh kelompok yang lebih besar dan terjadi penolakan dari kelompok yang lebih kecil. Selain itu kondisi tersebut juga didukung ketika kelompok yang lebih kecil tidak berusaha mengadopsi 
identitas budaya dominan. Sedangkan rejection dapat dikatakan sebagai penolakan dari kedua kebudayaan atau lebih yang saling bersinggungan.

Keempat jenis akulturasi ini dilihat Berry (1980) sebagai bentuk adaptif yang mendasarkan pada tiga tahapan utama terjadinya akulturasi, yaitu penyesuaian, reaksi, dan penarikan. Ketiga proses ini yang nantinya akan memunculkan jenis akulturasi apa yang digunakan. Pada tahap penyesuaian, seorang individu atau kelompok berusaha untuk menyesuaikan diri dengan kelompok lain. Kemudian dari proses tersebut muncul reaksi yang dihasilkan dari proses interaksi yang terjalin, sehingga pada tahap penarikan adalah tentang bagaimana kelompok bertindak sesuai dengan manifestasi dari proses interaksi yang panjang. Tahapantahapan ini juga tidak akan terjadi jika tidak terjalin komunikasi. Sesuai dengan Marden dan Meyer (1968) bahwa kunci dari proses akulturasi adalah komunikasi. Ia menerangkan bahwa selama proses akulturasi berlangsung, maka akan terjadi perubahan kebudayaan baik dari pendatang dan tuan rumah. Meski kecenderungannya akan lebih tampak pada kelompok pendatang yang diasumsikan sebagai kelompok yang lebih kecil. Meskipun istilah pendatang dan tidak juga menuai perdebatan. Tumanggor (2013), dalam studinya juga menilai bahwa keragaman orang-orang Indonesia didasari beberapa faktor sepertihalnya perubahan permukaan laut. selain itu yang tidak kalah penting disebabkan karena Indonesia ribuan tahun lalu merupakan wilayah yang menjadi jalur perlintasan laut yang dapat dikatakan sangat maju, tentu salah satu tujuannya adalah melakukan perdagangan. Melalui metode pelacakan genetika mithocondrial-DNA (Deoxyribo Nucleic Acid), Tumanggor (2013) bahkan berasumsi bahwa mungkin saja orang-orang Indonesia adalah Cina, meski ada beberapa temuan terkait persinggungan keturunan dengan bangsa-bangsa Eropa atau Amerika bahkan Afrika melaui jalur laut Asia-Pasific. Namun artikel ini tidak akan menjelaskan asal muasal etnis Tionghoa dan Arab di Banda. Persoalan etnis ini diambil berdasarkan beberapa kriteria penting seperti kemampuan kedua etnis tersebut dalam berkembang biak secara biologis dan bertahan hidup. Kemudian mereka juga memiliki nilainilai budaya yang secara sadar mereka yakini dan terapkan dalam kehidupan sehari-hari. Selain itu, yang tidak kalah penting yang digunakan dalam melihat etnis pada artikel ini adalah mereka memiliki jaringan komunikasi dan cara interaksi antarindividu dalam kelompok tersebut. (Liliweri, 2018) Hal ini dapat dilihat bagaimana etnis Tionghoa dan Arab memiliki forum komunikasi yaitu perkumpulan keluarga Tionghoa dan perkumpulan keluarga Arab. Fenomena ini menunjukkan bahwa meski perdebatan siapakah pendatang dan tidak di Indonesia, kasus etnis di Banda menunjukkan bahwa secara tidak langsung mereka mengidentifikasikan diri mereka dengan etnis yang berbeda.

Persoalan terkait dengan integrasi secara ekonomi-politik tidak lepas kaitannya dengan pemahama Marxis tentang materialism. Marx (1936) selalu menyebut bahwa semua hasil dari manifestasi interaksi masyarakat selalu didasari dari basis material. Artinya akulturasi dengan berbagai macam bentukannya juga dapat dikaitkan dengan bagaimana proses ekonomi-politik berlangsung dalam sebuah masyarakat yang terdapat dua budaya atau lebih yang saling berinteraksi. Ekonomi lebih kepada bagaimana mengelola basis material sebagai salah satu aspek penting untuk kelangsungan hidup, sedangkan politik digunakan untuk 
mengontrol dan menguasai dari sumber daya yang ingin diambil. Kedua aspek ini tidak dapat dipisahkan jika ingin digunakan dalam melihat akulturasi. Dapat dikatakan pula bahwa ekonomi dan politik tidak berdiri secara tunggal, melainkan menjadi kesatuan yang merujuk pada bentuk power yang digunakan untuk melihat bagaimana bentuk pengorganisasian dilakukan dalam sebuah masyarakat (Clammer, 1985). Oleh karena itu untuk menjelaskan bagaimana proses integrasid alam ekonomi-polotik yang dilakukan oleh etnis Tionghoa dan etnis Arab di Banda, artikel ini menggunakan pendekatan ekologi-politik.

Ekologi politik selalu dihubungkan dengan bahasan manusia atau masyarakat dengan alam. Mobergh (2013) dalam "Engaging Anthropological Theory", menjelaskan bahwa alam dan manusia menjadi hal yang tidak dapat dipisahkan. Pendekatan ekologi pada dasarnya dipengaruhi oleh studi geografi. Secara antropologis, hubungan alam dan manusia ini akan memunculkan jenis budaya tertentu. Kaitannya dengan budaya, melihat bahwa praktik budaya selalu memberi ruang bagi orang atau kelompok untuk beradaptasi dengan lingkungan. Bahwa praktik budaya yang kuat adalah praktik yang terkait dengan pemenuhan kebutuhan hidup dari populasi. Dalam "The Economic and Social Basis of Primitive Bands (1936)", Steward berusaha menjelaskan bahwa kondisi lingkungan dan teknologi mengarah pada terbentuknya organisasi sosial. Organisasi sosial inilah yang kemudian dianggap sebagai bentuk-bentuk kebiasaan yang melekat dan memunculkan praktik-praktik kebudayaan. Konsep yang digunakan oleh Steward ini menggunakan studi etnografi pada kelompok pemburu di Kalifornia Utara. Bahwasanya produksi konsumsi menjadi landasan utama terbentuknya praktik kebudayaan karena mereka menghabiskan banyak waktunya untuk menghasilkan kebutuhan makanan. Pada dasarnya waktu dari manusia lebih banyak dihabiskan untuk bekerja dan dengan kata lain dihabiskan untuk menghasilkan pemenuhan kebutuhan fisik. Tidak hanya makanan, bahkan kebutuhan tersier lain seakan menjadi kebutuhan yang penting. Ini menunjukkan bahwa interaksi antara alam dan kebudayaan seperti teori materialis yang mengasumsikan bahwa segala sesuatu yang ada dalam sistem budaya terjadi karena berdasar dari hal yang materialistik. Apa yang dijelaskan Steward ini tidak lepas dari pengaruh karya Harris yang mencampurkan konsep ekologi budaya dengan beberapa aspek teori Marxis. Marx menyebutnya sebagai materialisme kultural. Basis materialisme Marx menyangkut hubungan antara teknologi dengan hubungan sosial. Dengan kata lain, komponen yang mempengaruhi budaya adalah cara produksi dan hubungan sosial produksi tersebut.

Dalam perkembangannya, ekologi melalui perspektif materialistik sering dipadukan dengan kepentingan ekonomi dan politik. Kemunculan diskursus ekologi politik dalam studi antropologi dipelopori Eric Wolf (1972). Gagasan Wolf didasari pada kekuatan politik dan ekonomi yang mendorong deforestasi, degradasi lingkungan dan beberapa hal lain yang mempengaruhi alam dan kondisi sosial. Dalam studinya, Wolf melihat peranan ekologi politik dalam mengelola sumber daya yang ada di pegunungan Alpen. Untuk mempertahankan lingkungan atau bertahan dalam lingkungan tertentu, populasi harus mengatur sumber dayanya, apapun persyaratan yang harus dilakukan sesuai dengan apa yang diinginkan. Dalam penelitiannya di pengunungan Alpen bagian timur, terlihat bahwa pemanfaatan 
lahan pertanian dan perternakan dipercayakan kepada pihak yang secara hierarkis dianggap lebih tinggi. Proses kepemilikan sumber daya yang ada di kawasan tersebut dikelola secara politik karena berdasarkan basis kekuasaan. Kondisi ini kemudian menunjukkan adanya kecenderungan yang sangat kuat untuk melakukan konfederasi secara politik untuk menyatukan kepentingan bersama. Escobar (1998) juga berpendapat bahwa ekologi politik mempelajari masyarakat dengan alam dalam konteks kekuasaan. Beberapa studi lain memperlihatkan bahwa ekologi politik selalu erat kaitannya dengan studi konflik. Pichler dan Brad (2016) menyoroti berbagai macam konflik di Asia Tenggara, khususnya bagi beberapa negara yang terdampak kebakaran hutan. Dalam penelitiannya, Pichler dan Brad menekankan pada potensi transformatif untuk memobilisasi orang secara kolektif terhadap masyarakat yang tidak berdaya. Kelompokkelompok yang tidak berdaya tersebut dapat dikatakan sebagai kelompok rentan yang mendiami di beberapa wilayah dan tersebar antarlintas negara. Walter (2014) dalam penelitiannya di Amerika Latin juga berbicara tentang analisis gerakan lingkungan yang dilihat dari bingkai konflik karena memunculkan praktik-praktik organisasi sosial. Sebut saja Rokhani (et al, 2017) juga melihat bagaimana orang-orang Jawa berintegrasi dengan etnis Aceh di Simalungun. Studinya melihat bagaimana modal sosial diberlakukan terhadap sesama etnis Jawa dalam beradaptasi secara ekologis. Mereka menggunakan filosofi "Gemi, Nastiti, Ngati-ati" yang artinya hemat, cermat, dan bersahaja atau berhati-hati. Kondisi ini digunakan untuk melakukan perdagangan kopi arabika. Kondisi ini sesuai dengan Portes (1995) bahwa jaringan sosial adalah struktur yang penting sebagai modal informasi dan di dalamnya terkandung unsur ekonomi. Pada studi lain yang dijelaskan
Purbasari \& Suharno (2019) dalam interaksi sosial etnis Cina-Jawa Kota Surakarta juga menyoroti relasi antara etnis Cina sebagai pendatang dan etnis Jawa yang dominan di Surakarta sebagai tuan rumah. Selain itu Heath (et al, 2013) dalam "The Political Integration of Ethnic Minorities in Britain" melihat bahwa etnik minoritas menjadi salah satu bagian yang harus diintegrasikan dengan kepentingan politik di Britain. Studinya menekankan pada perilaku politik dan preferensi terhadap partai politik. Artinya dari beberapa studi tersebut pengorganisasian secara ekonomi-politis sangat kental dalam praktik pengorganisasian masyarakat.

Sebagaimana yang sudah dijelaskan sebelumnya, etnis Tionghoa dan Arab menjadi bagian yang tidak terpisahkan kaitannya menjadi Banda hingga saat ini. Mereka dapat dikatakan sebagai salah satu penggerak ekonomi-politik Banda hingga saat ini. Tak jelas kapan kedua etnis tersebut pertama kali sampai di Banda. Namun beberapa studi terkait menunjukkan bahwa interaksi pertama kali dengan dunia luar adalah dengan para pedagang dari Asia (Usman Thalib, 2015). Sudah sejak abad ke15 Banda dikenal melakukan perdagangan dengan Tionghoa dan Arab. Layaknya perdagangan pada umumnya, relasi yang dibangun memang didasarkan pada kebutuhan ekonomi. Bagaimana Banda sebagai pemasok barang dagang yaitu rempah, sedangkan para pedagang luar inilah yang kemudian membantu pemasaran ke luar Banda. Keberadaan mekanisme dagang yang terjadi di Banda kala itu tidak lepas dari peran orangkaya. Sebutan bagi tokoh yang secara ekonomi mapan dan secara politis mempunyai kedudukan wilayah di Banda. Mereka identik dengan kepala desa yang juga mempunyai kekuasaan yang sifatnya politik. Meski demikian, kehidupan masyarakat Banda 
terlihat harmonis dan seakan tidak ada perselisihan yang signifikan. Hubungan yang tercipta hanyalah relasi dagang. Hingga puluhan tahun kemudian, bangsa Eropa kemudian silih berganti berdatangan ke daratan Banda. Portugis, Inggirs dan Belanda menjadi cerita masa kejayaan sekaligus masa kelam bagi rakyat Banda.

Singkatnya 44 orangkaya Banda dibunuh oleh Belanda pada tahun 1621. Kondisi menjadikan stabulitas ekonomi dan politik terganggu. Selain itu VOC (Vereenigde Oostindische Compagnie) mengambil alih mekanisme dagang dengan monopoli harga dan seluruh aspek ekonomi dan politik. Secara tidak langsung, ada upaya politik ekologi dalam praktik tersebut. Kebijakan politik Belanda dengan membentuk sistem perkeniersstelsel untuk mengelola kebun-kebun pala menjadi bentuk politisasi sumber daya alam untuk diambil sebanyak-banyaknya nilai ekonomis dari rempah yang konon harganya melebihi harga emas. Kondisi tersebut berlangsung hingga terjadinya perjanjian Breda pada tahun 1667 yang berisi tentang penukaran wilayah koloni Belanda dan Inggris. Belanda memberikan daerah kekuasaannya yaitu Manhattan ke Inggris, sedangkan Inggris memberikan wilayah kekuasaannya yaitu Pulau Rhun di Banda ke pihak Belanda. Peristiwa tersebut juga merupakan wujud dari politik ekologi kaitannya dengan penguasaan secara penuh serikat dagang Belanda yaitu VOC untuk memonopoli rempah-rempah di Banda. Ratusan tahun kemudian hingga akhirnya pada periode 1890an kejayaan perkeniers pun juga turut usai. Kondisi ini yang kemudian bangsa-bangsa Asia kemudian kembali mengambil arena kepentingan ekonomipolitik. Dominasi etnis Tionghoa dan Arab sangat terasa. Namun di tengah runtuhnya kejayaan perkeniers dengan ditandai menurunnya harga pala dan fuli lantas apa yang kemudian dimanfaatkan.
Saat pertama kali tiba di Pelabuhan Banda, saya disambut oleh puluhan pedagang dadakan yang memang sengaja berjualan. Mereka adalah orang Banda. Tak jauh dari area pelabuhan, sedikit menyusuri ke selatan, terlihat satu-satunya pasar yang ada di Banda. Di pulau-pulau lain yang masih merupakan daerah administrasi Banda, tidak terdapat pasar. Pusat perputaran uang tertinggi ada di pasar yang tak jauh dari pelabuhan di Pulau Naira. Di tempat ini pula komoditas unggulan diperjualbelikan, seperti pala, fuli, dan bahanbahan pokok lain seperti singkong pun tersedia. Selain itu kebutuhan rumah tangga juga tersedia di sini. Pasar tersebut juga berdampingan dengan pelabuhan kecil sebagai dermaga tempat singgahnya kapalkapal dari beberapa pulau lain. Uniknya, hampir semua penjual di daerah tersebut beretnis tionghoa, meski ada beberapa pedagang lain di luar etnis tersebut. Benar saja, meski kawasan tersebut merupakan Desa Nusantara, namun masyarakat setempat menyebutnya sebagai Kampung Cina. Mereka berjualan mulai dari toko-toko kelontong kecil, kebutuhan rumah tangga, ada pula yang sebagai pemasok beras dan tengkulak pala. Selain itu, sumber daya yang dapat dimanfaatkan di Banda adalah ikan. Sumber daya ini sebenarnya tidak kalah penting dengan pala dan fuli, namun kedigdayaan rempah mendominasi bahwa satu-satunya sumber daya alam yang dapat dimanfaatkan di Banda adalah pala dan fuli. Meskipun demikian salah satu hal penting dari bisnis ikan di Banda adalah proses penyimpanan dan pendinginan ikan, atau yang biasa disebut cold storage. Akan tetapi, peluang tersebut nampaknya tidak mampu dimanfaatkan masyarakat Banda, para pengusaha yang bermain sebagai tengkulak ikan ini lebih banyak dari luar. Selain itu, komoditas unggulan ini tidak lepas juga dimanfaatkan etnis Tionghoa untuk turut membangun cold storage. Hasil wawancara dengan beberapa orang memang menunjukkan bahwa etnis 
Tionghoa cenderung menguasai ekonomi pasar. Secara politis jika etnis Tionghoa tidak ada di Banda, dapat dimungkinkan bahwa pasokan kebutuhan rumah tangga juga tersendat. Mereka berintegrasi dengan memanfaatkan modal ekonomi dan secara politis, mereka berpengaruh besar dalam kehidupan sosial. Kondisi ini tidak menjadi sebuah resistensi dari masyarakat setempat karena keberadaan etnis Tionghoa sangat membantu kebutuhan sehari-hari di Banda.

Lalu di mana etnis Arab? Jika merunut sejarah, mereka juga menjadi salah seorang pedagang layaknya etnis Tionghoa. Namun ratusan tahun kemudian, kondisi tersebut beralih. Beberapa dari mereka mengembangkan bisnis pariwisata. Ada yang membuat hotel dan jasa wisata. Hal ini terlihat jelas pada sosok almarhum Des Alwi. Pada masa pengasingan Bung Hatta dan Bung Sjahrir, Des Alwi diangkat sebagai anak. Hasil didikan tokoh-tokoh tersebut menjadikan ia sebagai tokoh nasional, bahkan sempat menjadi Dewan Pertimbangan Presiden (Watimpres) pada masa kepemimpinan Susilo Bambang Yudhoyono. Des Alwi adalah keturunan Arab-Maroko, meskipun demikian ia menjadi salah satu tokoh paling berpengaruh terhadap kemajuan Banda. Ketika ratusan tahun lalu rakyat Banda mengenal sebutan orangkaya yang terbagi sebanyak 44 orang, nampaknya sosok Des Alwi mampu menyatukan segala kekuatan ekonomi-politik para orangkaya tersebut pada kemudian hari. Wrangham (1999) bahkan juga menyebutkan Des Alwi menjadi pimpinan adat tertinggi walaupun berasal dari garis keturunan yang jauh berbeda dengan masyarakat Banda, meskipin posisi tersebut ia cipatakan sendiri. Apa yang dikatakan Des, diikuti oleh seluruh masyarakat Banda. Hal ini tidak terhindarkan karena ia mempunyai modal ekonomi yang tinggi, selain itu secara politik ia sangat berpengaruh. Ia juga yang mulai mengenalkan Banda sebagai salah satu destinasi wisata unggulan, bahkan hotel yang pertama kali berdiri di Banda adalah milik Des Alwi. Jasanya yang membuat perbaikan pada situs-situs sejarah melekat pada kehidupaan masyarakat. Kini, bisnis yang dimiliki Des, diwariskan ke keluarganya. Rosojati (dalam Budiman, 2019) juga menjelaskan bahwa bisnis pariwisata menjadi salah satu faktor pendukung perekonomian Banda. Salah seorang yang berpengaruh adalah Rizal Bahalwan, pria keturunan ArabJawa. Ia mempunyai hotel mewah di Banda, pun bisnis mutiara juga tidak dilewatkan. Seperti halnya Des Alwi yang dari kakeknya sebagai pengusaha mutiara. Rizal selalu dilibatkan dalam perhelatan akbar yang ada di Banda, bahkan sudah dapat dikatakan sebagai sosok yang dituakan. Etnis Arab dalam hal ini berperan dalam konteks ekonomi-politik dalam aspek wisata yang saat ini juga dikembangkan di Banda.

Pola-pola ini menunjukkan bahwa secara tidak langsung, kedua etnis tersebut yaitu etnis Tionghoa dan Arab berbagi peran dalam pemanfaatan sumberdaya ekologis. Proses pengintegrasian mereka dilakukan dalam aspek ekonomi-politik. Relasi ini jika dikaitkan dengan bentuk adaptasi merupakan wujud dari adaptasi secara ekologis (Alland, 1975).

\section{Simpulan}

Berdasarkan hasil penelitian, ada beberapa hal yang perlu dicatat dalam kasus etnis Tionghoa dan Arab di Banda. Proses interaksi yang panjang antara etnis tersebut dengan masyarakat Banda menciptakan mekanisme adaptif dalam pengelolaan sumber daya alam. Kondisi ini merupakan respon dari akulturasi yang hasilnya adalah pengintegrasian kepada kehidupan secara ekonomi-politik. Pengintegrasian tersebut merujuk pada saling menghargainya kebudayaan dan hubungan antarkelompok. Kondisi ini lebih dari sekedar toleransi. Toleransi hanya sekedar bagaimana menghormati dan menghargai perbedaan, 
namun dalam kasus ini, etnis Tionghoa dan Arab meskipun masih mengidentifikasikan dirinya sebagai sebuah etnis yang berbeda, namun ketika ditanya berasal dari mana, mereka menyebutkan sebagai orang Banda.

Bentuk integrasi yang dilakukan oleh etnis Tionghoa dan Banda dalam hal ini adalah dalam konteks ekonomi politik kaitannya dengan pemanfaatan sumber daya ekologis. Tionghoa menguasai ekonomi pasar. Sumber daya yang dikelola antara lain yang sifatnya komoditi seperti pala dan ikan. Etnis Arab dalam hal ini berusaha untuk mengeksplor sumber daya alam Banda untuk dijadikan magnet wisata dengan mendatangkan wisatawan serta menyiapkan infrasturktur lain. Etnis Arab melebur dan berintegrasi dengan masyarakat dengan turut serta ambil bagian dalam mekanisme pariwisata yang dibangun. Turut bersama-sama membangun aspek pariwisata di Banda secara bersamaan.

Kasus ini menunjukkan bahwa bentuk pengintegrasian dari etnis tidak hanya berada pada aspek kebudayaan, melainkan dalam ranah ekonomi-politik. Sebagai mana kita ketahui salah satu ciri kebudayaan adalah mata pencaharian yang konteks secara lebih luas dapat dikaitkan dengan praktik ekonomipolitik. Di Banda, Tionghoa dan Arab adalah etnis yang sama sekalai berbeda dengan masyarakat Banda, namun mereka dapat berintegrasi dalam kehidupan sosial, ekonomi, politik.

\section{Referensi}

Alland, Jr. Alexander. 1975. Adaptation. Annual Review of Anthropology. Vol 4, (59-73)
Berry, J.W. 1980. Acculturation as varieties of adaptation. In: Padilla, A., Ed., Acculturation: Theory, Models and Findings. Westview, Boulder. (9-25).

Budiman, Hikmat. 2019. Ke Timur Haluan Мепијu. Jakarta: Yayasan Obor Indonesia.

Clammer, John. 1985. Anthropology and Political Economy: Teoritical and Asian Perspective. New York: St. Martin Press.

Escobar, Asturo. 1998. Whose Knowledge, Whose nature? Biodiversity, Conservation, and the Political Ecology of Social Movements. Journal of Political Ecology, Vol 5.

Gillin and Gillin, 1954. Cultural Sociology: A Revision and of an Introduction to Sociology. New York: The Macmillan Company.

Guarnaccia, Peter J. \& Stabile, C.H. 2016. Acculturation and Its Discontents: A Case for Bringing Anthropology Back into the Conversation. Sociology and Anthropology 4, no. 2 (114-124).

Heath, F. Anthony (et al). 2013. The Political Integration of Ethnic Minorities in Britain. England: Oxford University Press.

Lape, Peter V. 2000. Political dynamics and religious change in the late pre -colonial Banda Islands, Eastern Indonesia" World Archaeology 32, no. 1 (138-155)

Liliweri, A. 2018. Prasangka, konflik, dan komunikasi antarbudaya. Jakarta: Kencana. 
Marden, C.F \& Meyer, G. 1968. Minorities in America Society. New York: American Book Co.

Marx, Karl. 1939. Grundrisse. Jerman: Penguin Books.

Milton, Giles. 2015. Pulau Run: Magnet Rempah-rempah Nusantara yang Ditukar dengan Manhattan. terj. Ida Rosdalina. Tangerang Selatan: PT Pustaka Alvabet.

Moberg, Mark. 2013. Engaging Anthropological Theory: A Social and Political Theory". New York: Routledge.

Nwadoria, E \& McAdoo, H. 1996. Acculturative stress among Amerasian refugees: gender and racial differences" Adolescence, Summer.

Pichler, M., \& Brad, A. 2016. Political ecology and socio-ecological conflicts in Southeast Asia. ASEA Austrian. Journal of South-East Asian Studies, Vol 9, no. 1 (1-10).

Portes, Alejandro. 1995. Economic Sociology of Immigration, The Essays on Networks, Ethnicity, and Entrepreneurship. New York: Russel Sage Foundation.

Purbasari \& Suharno. 2019. Interaksi Sosial Etnis Cina-Jawa kota Surakarta". Jurnal Antropologi: Isu-isu Sosial Budaya. Vol 21, No 1.

Rokhani (et al). 2017. Javanese Diaspora and Adapted Ecology of Java Ethnic in Simalungun North Sumatra. Journal of Arts, Science \& Commerce. Vol VIII, No 4.
Schwartz, Seth J., et al. 2010. Rethinking the Concept of Acculturation: Implications for Theory Research. Am Psychol 65, no 4 (237-251).

Steward, Julian. 1936. "The Economic and Social Basis of Primitive Bands (1936)", Berkeley: University of California Press.

Teske JR, Raymond H. C. \& Nelson, Bardin H. 1974. Acculturation and Assimilation: A Clarification. American Ethnologist 1, no 2 (351 367).

Thalib, Usman and Ramlan, La. 2015. Banda dalam Sejarah Perbudakan di Nusantara Yogyakarta: Penerbit Ombak.

Tumonggor, Meryanne. (et. al)., 2013. The Indonesian archipelago: an ancient genetic highway linking Asia and the Pacific. Journal of Human Genetics 58, 165-173.

Van Hoevel, W. R. 2014. Sejarah Kepulauan Maluku.terj Harto Juwono. Yogyakarta: Penerbit Ombak.

Villers, John. 1981. Trade and Society in the Banda Islands in the Sixteenth Century. Modern Asian Studies. Vol. 15 , No 4 (723-750).

Walter, Mariana. 2014. Political Ecology of Minig Conflict in Latin America: An Analysis of Environmental Justice Movements Struggles Over Scales. Universitat Autonoma de Barcelona, $\mathrm{PhD}$ Programme in Environmental Sciences. 
Weinstock, S. Alexander. 1969. Acculturation and Occupation: A Study of the 1956 Hungarian Refugees In the United States. Netherlands: Martinus Nijoff.

Wirth, Louis. 1941. Morale and Minority Groups. American Journal of Sociology. Vol. 47, No 3 (415-433).

Wolf, Eric. 1972. Ownership and Political Ecology: Dynamics of Ownership in the Circum Alpine Area (Special Issues). Anthropological Quaterly, Vol. 45, No 3 (201-205).

Wrangham, Rachel. 1999. Management or domination? Planning tourism in the Banda Islands, Eastern Indonesia. International Journal of Contemporary Hospitality Management. vol 1 (111 $115)$. 